\title{
The Akan experience of God through the eyes of the Fante from Oguaa
}

\begin{abstract}
Any group of people or society that embraces religion has an experience or a concept of who they perceive to be the Center of the religion or who they consider to be the Supreme Being. The Akan of Ghana as an African people are religious and for that matter has an experience of the Supreme Being. This paper sought to share an Akan experience of God from the perspective of the Fante of Cape Coast (Oguaa). The synthetic and interpretative approaches were used in addition to collection of data from some elderly people, traditional priests and court historians from Oguaa. The indigenous people believe in the Supreme Being (God) as the Creator. They have three distinct names for God and these names show their understanding of who God is. These names are Onyame, Onyankorpon and Ddomankoma. There are seventy-seven deities that are recognized and accepted in the Oguaa traditional area. These deities are believed to be children of God; the Supreme Being and He has assigned them to the people for protection and other assistance. Also, in spite of the recognition and acceptance of these deities, the indigenous religion of the people should not be classified as polytheistic. Their religion should be described as henotheistic.
\end{abstract}

Volume 3 Issue 6 - 2019

\author{
Leo Andoh Korsah,' Jonathan ET Kuwornu- \\ Adjaottor $^{2}$ \\ 'Department of Arts and Social Sciences, Methodist College of \\ Education, Ghana \\ ${ }^{2}$ Department of Religious Studies, Kwame Nkrumah University \\ of Science and Technology, Ghana
}

\begin{abstract}
Correspondence: Jonathan ET Kuwornu-Adjaottor, Department of Religious Studies, Kwame Nkrumah University of Science and Technology, Kumasi, Ghana, West Africa, Email jkadjaotto@gmail.com
\end{abstract}

Received: November 15, 2019 | Published: December 05, 2019

Keywords: belief, deities, indigenous, supreme being, traditional

\section{Introduction}

Authors including Nkansa-Kyeremanteng ${ }^{1}$ and Asiamah $^{2}$ have researched into and written on general subjects about the Fante of Cape Coast without giving much attention to the indigenous religion of the people. Most scholars from outside Ghana have also studied into African indigenous religions and the Akan concept of God with emphases on the Asante to the neglect of the Fante. In this paper, the writers share an Akan experience of God from the perspective of the Fante from Oguaa through synthetic and interpretative approaches. The synthetic approach is used because the authors have collated views of some scholars and utilized for more comprehensive knowledge on the topic. The interpretative approach is also at play because of the writers being Ghanaians who have once lived in Oguaa and have some experience in participant observation of the religion of the people. In this regard, the views of some elderly people, traditional priests and court historians were sought. In sharing the experience of God from the Fante perspective, this paper provides an overview of the Oguaa indigenous religion, the indigenous Fante names of God and finally draws a conclusion on the discussion.

\section{A brief overview of the Oguaa indigenous religion}

Religion has been identified with the people of Oguaa since antiquity and there is no specific person that can be identified as the founder of the indigenous religion. However, in Oguaa mythology, there is the heroic character who stands out because of his love and contribution to the indigenous religious practices and Oguaaman $n^{\mathrm{ii}}$ as a whole. There was an epidemic and the gods required human sacrifice for atonement in order to halt it. This requirement seemed absurd to the people as it was the first ever required human sacrifice in the land. A man by name Agya Oguaa offered himself to be sacrificed for the

${ }^{\mathrm{i}}$ Oguaa is the traditional name for Cape Coast.

${ }^{i i}$ Oguaaman refers to the Cape Coast Traditional area atonement and the purification of the land. This marked the end of the epidemic. The act of Agya Oguaa made the people more devoted to their indigenous belief in the activities of their gods. Although the religion existed before him it is a belief among the indigenous people that the act of Agya Oguaa saved Oguaaman and also aided the survival of the indigenous religion till today. ${ }^{\mathrm{iii}}$ There are no missionaries to propagate this religion ${ }^{\text {iv }}$ but Agya Oguaa though dead, is regarded as the living missionary of the indigenous religion. The indigenous religion is very broad and accommodates some practices of other faiths. In spite of its broad nature, there are some essential features that mark off the religion from other missionary faiths and some of these include: belief in ancestors, belief in lesser deities and belief in the Supreme Being (God). The ancestors are those who were morally upright while living, fulfilled their mission in the community and died natural and peaceful deaths. Seth Asare-Danso infers from J.S. Pobee ${ }^{v}$ to affirm that ancestors were part of the clan and have completed their course of journey on earth and have gone ahead to live in the other world ${ }^{\mathrm{vi}}$. They are revered, honored and regarded as the custodians and the guardians of the land. This belief is common to all African indigenous religious practitioners. Another belief is the belief in smaller deities. They are regarded as the children of God and derive their powers from their Father the Supreme Being for specific duties that He assigns to them. The recognized smaller deities in Oguaa are seventy-seven ${ }^{\text {vii }}$ in number. All these seventy-seven children are spirits, have personal names and dwell in stones, rocks,

iiiThe source of information on the Agya Oguaa myth is Supi Kobina Minnah, the head of the number six Akrampa Asafo Company who doubles as an okyeame and a court historian

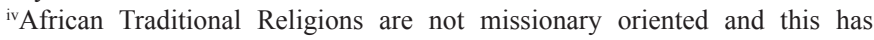
been espoused by almost all scholars who attempt to give an account of the indigenous religions of Africa.

vobee JS. Toward an African theology. Nashville: Abingdon Press; 1979.

${ }^{v i}$ Asare-Danso S. African Traditional Religion. Cape Coast: Beret Outlook Press; 2019.

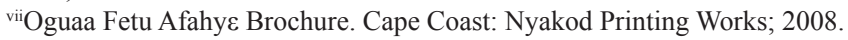


tree, groves and so on. They all have their specific shrines where rituals are performed in their honor ${ }^{\text {viii }}$. These are agents of God and

viiiThese are the personal names of the seventy-seven deities and their specific places of location: 1. Nana Tabir: a rock in a creek in South-eastern part of Cape Coast and in the end of the right dungeon of the Cape Coast Castle. 2. Nana Paprata: a large depression under Kingsway store and Tema Food Complex Corporation building in Cape Coast with water flowing into the sea now covered with swish. 3. Nana Fosu: Cape Coast Lagoon - west of the town. 4. Nana Aduia: a rock on site between old Methodist cemetery and second mission house. 4. Nana Etuel: a stone in a shrine at the south-east of the police station. 5. Kotowuraba: a stream once flowing from Minnow street in Kotokuraba in and enters into the sea. 6. Abaka Awuonsu: a pond at Siwudu village in Cape Coast. 7. Nana Abuaku: a stream running from the valley of first ridge and enters Tantri via Agriculture Station and Electricity Corporation area in Cape Coast. 8. Nana Nkenyi: a stream flowing from the valley of the hills at Amanful. 11. Nana Sapraku: a stone, which was at the eastern side of the Methodist Church where a chop bar is erected. It has now been relocated to OLA and placed among the gods of No. 1 Asafo Company. 12. Nana Akutompo: a grove at Emisa- ekyir (King Aggrey Street), now cut away. 13. Nana Amissa chain of stones behind north-east of present No. 5Asafo Company Post. 14 Nana Kumkensen: a genius giant once in Abowinim (Jerusalem Street) site of Basel Mission Church. 15. Nana Ante -Yesu: pond at Siwudu village. 16 Worakobir: a pond once in the area lading to the site of the District Education Office. 17. Nana Antotsefi: a rock in the sea at Idan. 18. Nana Anyitswi: chain of stones in hillock between Idan and Amanful. 19. Nana Buranta: a rock in the sea in Elmina road. 20. Nana Bentum: a rock in Kukwadu village near the University of Cape Coast. 21. Bonso-Adai: foot of the hill where Frederickborg was built at Amanful. 22. Nana Ekyinaba: a stone a shrine at Tamirisasi. 23. Nana Tankuferdu: an area in which black broken earthen wares were always found near Adisadel. 24. Nana K-ntamtwom: a rock between Abaka Brony and Bontsin. 25. Nana Adamba: a stream flowing into the sea at AmanfulAbanakyir. 26. Amunakofua: a stream flowing into the sea between Amanful and Amunakofua. 27. Bontsin: a high rock between Ekon and Cape Coast. 28 Nsatiakor: a stone on Abrofo Mpoanu. 29. Nana Gya-gyi: a stone in southern part of the Cape Coast GNTC building (now Melcom). 30. Nana Bosomefi: a stone lying about 200 meters away on southern side of the Commercial Bank in Cape Coast. 31. Nana Sankrodu: a pond at Siwudu village in Cape Coast. 32. Nana Akwaabram: a grove behind Central hospital now cut away. 33. Nana Antowuraba: a stream flowing from North West of Antem School. 34. Nana Edum-ekyir: an oak tree in Apewosika village. 36. Nana Buraba: a pond in OLA behind Medina in Cape Coast. 37. Nana Nkodwobum: a hillock on which pieces of manganese were found at Abowinmu. 38. Nana Ako-nsu: a rock in a hole at University of Cape Coast bungalow No.18. 39. Nana Dumanta: a stone in a shrine at old Bentsir quarters now removed to OLA and placed among the gods in the Company Post. 40. Nana Ebokwesi: a stone in Kukwado village. 41. Nana Gyankobir: a hill on western side of Beulah lane. 42. Nana Biba Tsintsin: a rock in front of Abrofo Mpoanu. 43. Nana Abaka Tunfu: a rock in a grove at Kwesi Ipra village. 44. Nana Saadwi: a rock in Asikam Mpoanu. 45. Nana Tsimtsimhwe: a stream flowing from Mfiriisim into Fosu lagoon. 46. SaSa Kwesi: a rock in Amamoma village, a god in charge of battle line. 47. Nana Mponasi: a tree in the Cape Coast University maintenance yard. 48. Nana Mpona: a rock in the sea near Duakor. 49. Nana Adam: a rock in Akyim village. 50. Nana Abaka: a rock at the right side of Abakam, Elmina Road. 51. Nana Tansar: a rock in Abrafo Mpoanu. 52. Duakor: a rock in the sea but its shrine is on the way to Kukwado village near the university. 53. Nana Bura: a pond from which a stream flow into Anowuraba. 54. Nana Mbodambo-mbodambo: a stone once in the site between Central Hospital and Fosu lagoon. 55. Emutu: a lagoon at Ekon. 56. Abosantsin: a rock at Aban-akyir. 57. Kwesinyinmarfo: a stone which was on the south of the Victoria Park now removed. 58. Nana Gye-gya: a conspicuous tree standing on the southern side of the Socia Welfare Office in Cape Coast. 59. Nana Abaka Bonso: a rock in Idan Sea. 60. Nana Boambradu: a rock in the Idan Sea. 61. Nana Asika: a rock in shore to rocky lane. 62. Nana Biba Kessi: a rock adjacent to Akroma Kodwo. 63. Nana Ekumbrofu: a rock in the sea at Abrofu-Mpoanu. 64. Nana Ben Koko: a stone in a grove behind Black Star on Cape Coast, OLA to Elmina road. 65. Nana Akroma Kodwo: a rock in the sea in front of the large rock in south-eastern part of the castle. 66. Nana Bakumpe: a pond at Apewosika village. 67. Nana Gyambibir: a huge stone with smaller ones at the northern area of Water and they protect all inhabitants of Oguaa. These gods, spiritually, steer the affairs of the Oguaa traditional area and also the success of the Oguaa fetu afahycix depends on them. At every festival, sacrifice is offered to all at their various shrines. These are the traditionally recognized and accepted ones that Oguaaman calls on in times of problems for assistance. They can bring blessings and curses upon the individual and the state depending on how they are responded to. It is believed that on Thursdays, all the lesser deities (77 children of God) leave the earth to meet Onyanksrpsn ${ }^{\mathrm{x}}$ concerning Oguaaman. They are not invoked on Thursdays because they do not respond to the call of men while in the presence of Onyankorpon. Any god that appears on Thursday is evil and has no good intention for the individual and Oguaaman at large. The earth is also believed to be a goddess by the name Asaase Afua. She was created by God and is regarded as His wife. She has been put in charge of farming by the Supreme Being. The people of Oguaa acknowledging the existence of smaller deities besides the Supreme Being does not make them polytheistic. To refer to them as polytheists will be a hasty conclusion, it is better to classify their religion as henotheistic.

In his contribution on the nature of African Traditional Religion, Kwame Gyekye asserts that "God is the supreme being but not the object of direct worship". For him, the recipients of worship are the other deities that may dwell in trees, rocks, mountains and rivers although the African religion is not nature worship. ${ }^{\mathrm{xi}}$ It seems his assertion is a generalization which one needs to be cautious of in pushing too far because other African writers such as John S. Mbiti have made us understand that although worship may be directed to spirits and the ancestors, they are only regarded as intermediaries between the Supreme Being and men "so that God is the ultimate recipient whether or not the worshippers are aware of that". ${ }^{\text {ii }}$ Kwame Gyekye's generalization is not applicable to the people of Oguaa because the gods are children of the Supreme Being who act as intermediaries and are not the final recipient of worship. The indigenous people have a strong belief that God is a spirit who cannot be seen yet his presence can be felt. He is the Supreme Being who is the Creator and Centre of all that there is and the mover of all. The question of whether God exists or not is never asked among the people of Oguaa. Whoever dares to ask such a question is assumed to have mental illness. Atheism or agnosticism is not accommodated in the land of Oguaa; the atheist will not be regarded as Nyimpa adasa. ${ }^{\text {xiii }}$ This is to imply that the people of Oguaa takes for granted the existence of God. The belief in God is expressed in names such as Nyameakyedzi. ${ }^{\text {xiv }}$ The belief is also expressed in maxims such as: Obi nkyere abofra Nyam $^{\mathrm{xv}}$

Sewage Corporation Office at Cape Coast. 68. Nsokora: a rock behind the Cape Coast Castle in south-west. 69. Nana Biba Kessi: a rock behind the house of the head of Ebiradze family. 70. Nana Ibintutu: a rock in Idun Sea. 71. Nana Abaka Bronyi: a rock in the distance between Amunakofua and Bontsin. 72 . Nana Ayenbiba: a rock on shore in front of Etueyi. 73. Nana Burabin: a tree at the University of Cape Coast transport yard. 74. Nana Dawiamu: a stone once in warders' quarters. 75. Nana Miribimko: a bird at the Fosu lagoon area known to be removing fallen leaves from the water. 76. Nana Eukyia Miensa: a triangular stone at Amanful Abanakyir. 77. Nana Senaman: a stone that emits fire when and where necessary at the No.1 Asafo Company.

ix The traditional festival of the people of Cape Coast (Oguaa). It is celebrated in the first week of September

${ }^{\mathrm{x}} \mathrm{An}$ indigenous name use for God

${ }^{x i}$ Gyekye K. African Cultural Values. Accra: Sankofa Publishing Company; 1996.

xii Mbiti JS. African Religions \& Philosophy. London: Heinemann; 1969

xiiilt refers to a human being with a moral conscience

xivIt means a gift from God

xviterally means no one shows the child God 
and Aboa onyi dua, Nyame na spra no ho. ${ }^{\text {xvi }}$ Meanwhile, in discussing the origin of the African belief in God, John Mbiti suggested three reasons that could have led to the African belief in God and these were: his reflection on the creation of the universe, realization of his limitations and weaknesses and thirdly his observation of the forces of nature ${ }^{\text {xvii }}$. These suggestions imply that there was a point in time that the African did not believe in God but this cannot be said of the people of Oguaa.

\section{Indigenous names of god}

According to Kofi Asare Opoku, all African societies have specific names for God which express the African idea of the uniqueness of God $^{\text {xviii. }}$. Most of these names are true reflection of the attributes given to God. In this paper, there is a discussion on some indigenous Fante names of God and how they correlate with the attributes of God in the life and thought of the Oguaa people. Names are very significant in the Fante culture. Names are to give specific identity to the bearers. The one who bears the name must be worthy of it and must live the implication of the name. Names are believed to influence the character of the person. It is only those who are accepted as legitimate members of the family that are given names in the family. T.N.O. Quarcoopome writing on the Akan concept of God, provides three Akan names of God- Onyame, Onyamkopon and Onyamkopon Kwame. He asserts that Onyame is derived from "nya" (to get) and "me" (satisfy) which makes it reasonable to infer that Onyame means "the God of fullness" or "the God of ultimate satisfaction" xix. In his extensive contribution to the Akan meaning of God, J.B. Danquah mentions three names of the Akan God and these are: Onyame (the Akan Deity), Onyamkopon Kwame (the God of Saturday) and Ddomankoma (the infinitely manifold God). He does not subscribe to the assertion that Onyame is derived from "nya" (to get) and "me" (satisfy). He therefore does not subscribe to the interpretation that Onyame means "God of fullness" or "God of ultimate satisfaction". For J.B. Danquah, "Onyame is from Nyam; shining, glory or bright and there are still people who pronounce Nyame as Nyam ' in poetry." He posits that "the Akan root name for Deity is Nyam, Shining One". ${ }^{\text {xx }}$ The people of Oguaa seem to affirm this position.

The indigenes of Oguaa use three distinctive names for the Supreme Being. These names bring to light the thoughts of the people concerning the Supreme Being. These names were not revealed to them by the Supreme Being as He revealed his name to those in other religions such as Islam and Judaism. These names were constructed by the indigenes from how they experience the Supreme Being. The three distinctive names use for the Supreme Being are: Onyame, Onyankopon and Jdomankoma. All other names used apart from these three are His attributes. The most used name of the Supreme Being among Akans in general is Onyame. Anthropologists such as Rattray and Field have made us believe that Onyame is the sky God. ${ }^{\mathrm{x} i}$ Until recently the sky God was not thought of as the Supreme Being, therefore to say that Onyame is the sky God is a wrong perception of the African belief in the Supreme Being. Perhaps associating Onyame

\footnotetext{
${ }^{x v i}$ Literally means that it is God who cleanses the tailless animal

xvii Mbiti JS. Introduction to African Religion. 2nd edition. Oxford: Heinemann International Literature and Textbooks; 1991.

xviii Opoku KA. West African Traditional Religion. Accra: FEP International Private Limited; 1978.

${ }^{x i x}$ Quarcoopome TNO. West African Traditional Religion. Ibadan: African

Universities Press; 1987.

${ }^{x x}$ Danquah JB. The Akan Doctrine of God. London: Frank Cass and Company Limited; 1968.

xxiJB Danquah. The Akan Doctrine of God. 31, 32, 33
}

with the sky God arose out of the Akan myth of the old lady pounding fufu who drove God away with her long pestlexii or the myth of the woman who used to cut the clouds into her soup or the one who usually washed her dirty hands in the clouds. These myths express the notion that Onyame moved far away into the sky. We need to acknowledge that the name Onyame was not coined purposely for the myth. The name Onyame has existed in the mind and on the tongue of the people long before the myth was said. Myths are not mere imaginary stories or fictions but expression of fundamental truths on issues such as how humanity came into existence and the purpose of humankind's existence. ${ }^{x x i i}$ The significance of a religious myth does not depend on historicity of its content but the moral truth that it imparts. The essence of these myths concerning Onyame moving far into the sky is to elaborate the fact that in Akan religious thought, sin creates a big distance between nyimpa dasanyi (human being) and Onyame, so there is the need to avoid sin. Once Onyame has nothing to do with the sky God, then what is the meaning of such a name?

The meaning of the name is rooted in its etymology. There are two schools of thought concerning the etymology of the name. According to one school of thought championed by J.B. Danquah, Onyame or Nyame is derived from the word enyim-nyam literally meaning splendor of the face, shining, bright, glory, excellency, honor, dignity. Enyimnyanfo translated into English is a dignified, distinguished or honorable person. Onyame as a name of a Supreme Deity is the Shining One and His nature is the Shining Power which is evident in one of His appellation Amowia, the Giver of Light or Sun. From Danquah's perspective the name could mean the most honorable in the society. ${ }^{\text {xxiv }}$

The other school is of the opinion that two words are joined together to form Onyame. These words are onya meaning he gets and men which means satisfy. If this is true then the original name will be Onyamen. This will literally mean he gets satisfied. The pronoun ' $O$ ' (he or she) is sometimes ignored and the name becomes Nyame. This will explain the meaning of the name better; it literally becomes 'get and be satisfied'- "enya n'amen". Onyame as the name of a Supreme deity in the minds of the people of Oguaa means the one who is full of satisfaction or the one who is needed to attain fullness or satisfaction. In the minds of the indigenes nyimpa dasanyi (human being) is not complete and is hungry for something beyond his very nature so he gets satisfied when he contacts the Supreme Being; Onyame. The name points to the sufficiency of the Supreme Being and resonates the notion that when you have him you need no other person. ${ }^{x x}$ Most of the people in Oguaa today are ignorant of Danquah's view. Although his etymology is traced from a different word as compared to what is held by the Oguaafo, it takes nothing away from both schools. It is highly important to note that the two different sources of Onyame as a name of the Akan Deity postulate him as the most important and the most sought-after. He is indeed the Supreme Being, the all in all. Onyame can be written starting with a small letter as 'onyame' and this is referred to a smaller deity. When used as a smaller deity it can be pluralized as anyame (smaller gods). It has its plural form because the other deities or gods are numerous and are all children of the Onyame. One should take note that Onyame as the Supreme Being cannot be pluralized because $\mathrm{He}$ is One.

\footnotetext{
xxiiKA Opoku K. West African Traditional Religion. 23, 24.

xxiii Asare-Danso S, Thompson M. Religious Experience of Humankind. Cape Coast: Beret Outlook Press; 2019.

xxiv JB Danquah. The Akan Doctrine of God. 36-39.

${ }^{x x}$ According to Supi Kobina Minnah, the head of the number six Akrampa Asafo Company who doubles as an okyeame of the Oguaa traditional council in an interview dated 22nd July 2019; this is what Oguaaman holds on to.
} 
Another name for God among the people from Oguaa is Onyakopon or Onyaksrpon. The ' $O$ ' in Onyakopon or Onyaksrpon is not a mere letter but a pronoun. This pronoun can be ignored as it is in Nyame and it does not affect the meaning of the name. The people of Oguaa are as at today divided concerning this name of the Supreme Being. A section of the people calls him Nyankopsn while the other section also refers to him Nyanksrpon. The division over the correct pronunciation is a healthy division as it postulates the various nature of God in the life and daily experience of the indigenes of Oguaa. This is their tradition that has been handed over to them by their ancestors. Nyankopon is an amalgamation of two separate Fante words and these are: the noun 'nyanko' (friend) and the suffix 'pon' (great, huge, big etc.). 'Nyanko' is a singular word so when amalgamated with 'pon' it renders the meaning 'a great friend'. In this instance the indigenous people in their earliest days knew God to be a great friend. When they speak of Nyankopon they mean a dependable friend who will never let them down. It is expressed in the name Twereduapon Nyankopon. They see a kind of friendship in him that surpasses that of marriage couples. The friendship between the husband and the wife can be dissolved but that of Nyankopon is everlasting. This also portrays their absolute trust in depending on the Supreme Being as a deity to be worshipped above all deities.

There is also an interesting and wonderful assertion about the name Nyankorpon by Ebow Johnson. ${ }^{\text {xxvi }}$ For him, the actual name is a full sentence "Nyame kor pon", but for the sake of easy pronunciation in communication it has been made Nyanksrpon. From this perspective the name is built around the most common name among Akans for God and that is Nyame. 'Kor' in the Fante language means one, alone or single. ${ }^{3}$ We can therefore conclude that Nyankorpon means the only great one needed to be satisfied. In using either of the two we need to know that it is a religious name mostly used during prayer. For religious purposes especially in libation prayer Kwame is added to it. The name becomes Onyankopon Kwame giving the notion that he is a Saturday born as it is only those born on Saturdays who take the name Kwame. In the thoughts of the people, Onyankopon is not born on Saturday because none gives birth to the Pboadzi (Creator) Nyankopon. The Kwame proves that he is a personal God and there is the possibility of him getting personal with his devotees. Once again, the personal name chosen is Kwame and not any other kra dzin ${ }^{x x v i i}$ because it is traditionally believed that Onyankopon created nothing on this day - Saturday. ${ }^{\text {xxviii }}$

The third name used by the people is Jdomankoma, the people of

\footnotetext{
${ }^{x x v i S u p i}$ Ebow Johnson of number one Ntsin Asafo Company of the Oguaa traditional council. He made this assertion in an interview on 15th February 2010 .

xxvii Soul names. They are names given based on the day of birth.

xxviii This was revealed to us by Nana Komfo Araba who has been a traditional priest for the past forty years on 11th February 2019 and confirmed by Supi Minnah on 22nd July, 2019
}

Oguaa are very much enthused about this name. They are not bothered about the etymology of the word, what matters to them is what it means. Ddomankoma, according to Supi Minnah in an interview on 22nd July 2019 implied that God has no beginning and end. There are also few people ${ }^{\text {xxix }}$ who try to break the name into parts to explain its meaning. In doing this it is divided into three parts and these are 'Ods' (love), ' $m a$ ' (full), and ' $n k o$ ' (alone), this renders the meaning he who is alone yet full of love. In this breaking down of the name, the last ' $m a$ ' is not talked about because its meaning (full) does not change. The name emphasizes on the fullness of God. It seems to us that this second view could be a later development that was influenced by Christian thoughts.

\section{Conclusion}

In the discussion so far, we have established that in spite of the broad nature of the indigenous religion practiced by the Fante from Oguaa, three essential features mark off the religion from missionary religions and these are: belief in ancestors, belief in lesser deities and belief in the Supreme Being (God). The indigenes of Oguaa use three distinctive names for the Supreme Being and these names bring to light the thoughts of the people concerning the Supreme Being. The three distinctive names use for the Supreme Being are: Onyame, Onyankopon and Ddsmankoma. All other names used apart from these three are His attributes. For the people of Oguaa, there are seventy-seven official deities recognized as children of the Supreme Being who have been assigned to protect and give assistance to the indigenous people.

\section{Acknowledgments}

None.

\section{Conflicts of interest}

The authors declare that there is no conflict of interest.

\section{Funding}

None.

\section{References}

1. Kyeremanteng KN. The Akans of Ghana: their customs, history and institutions. $2^{\text {nd }}$ edition. Kwahu: Sebewie Publishers; 2008.

2. Asiamah EAA. The Mass Factor in Rural Politics. Accra: Ghana University Press; 2000.

3. Oduyoye MA. The African Experience of God through the Eyes of an Akan Woman. The English Jesuit Journal of Spirituality; 1997.

${ }^{x x i x}$ Such people include Maame Efua Blankson, an eighty-five-year-old woman at Kotokuraba who we interviewed on 27th June 2019. 